\title{
A RELATIONSHIP BETWEEN ECONOMIC PERFORMANCE AND AIR POLLUTION OF A SCIENCE PARK: A CASE STUDY OF HSINCHU SCIENCE PARK IN TAIWAN
}

\author{
HUANG, S. Z. ${ }^{1}-$ CHAU, K. Y. ${ }^{*}-$ SHEN, H. Z. ${ }^{3 *}-$ LI, J. ${ }^{4}$ \\ ${ }^{I}$ School of Economics and Management, Guangdong University of Petrochemical Technology \\ Maoming, China \\ ${ }^{2}$ Faculty of International Tourism and Management, City University of Macau, Macau, China \\ ${ }^{3}$ College of Chemical Engineering, Huaqiao University, Xiamen, China \\ ${ }^{4}$ School of Business, Macau University of Science and Technology, Macau, China \\ *Corresponding author \\ e-mail:gavinchau@cityu.mo; hzhshen@hqu.edu.cn \\ (phone: +853-8590-2518; fax: +853-8590-2518)
}

(Received $4^{\text {th }}$ Sep 2018; accepted $15^{\text {th }}$ Oct 2018)

\begin{abstract}
Rapid economic development has caused serious air pollution which threatens human health. Science parks play an important role in economic development, however their air pollutants deteriorate the ambient air quality. This study investigates the relationship between the economic performance and air pollution of Hsinchu Science Park in Taiwan, which is the biggest production base of semi-conductors and other relevant high-tech industries. The total business turnover and annual average concentrations of sulfur dioxide $\left(\mathrm{SO}_{2}\right)$, ozone $\left(\mathrm{O}_{3}\right)$, nitrogen oxide $\left(\mathrm{NO}_{\mathrm{x}}\right)$, carbon monoxide $(\mathrm{CO})$ and particle matter with aerodynamic diameter less than $10 \mu \mathrm{m}\left(\mathrm{PM}_{10}\right)$ of Hsinchu Science Park from 1993 to 2012 were employed for the analysis. Vector Auto Regression (VAR) model was used to analyze the relationship between economic performance and air pollution for Hsinchu Science Park. The results indicated that there was a close, long-term and stable relationship between economic performance and air pollution concentrations in Hsinchu Science Park. A significant hysteresis effect of the economic performance was observed on the $\mathrm{O}_{3}$ and $\mathrm{CO}$ concentrations, while a weak hysteresis effect of that was revealed on the $\mathrm{SO}_{2}$, $\mathrm{NO}_{\mathrm{x}}$ and $\mathrm{PM}_{10}$ concentrations. The increasing emissions of $\mathrm{O}_{3}$ and $\mathrm{CO}$ resulted from the production expansion. By contrast, $\mathrm{SO}_{2}, \mathrm{NO}_{\mathrm{x}}, \mathrm{PM}_{10}$ were not affected by the growth of economic performance of Hsinchu Science Park.
\end{abstract}

Keywords: total business turnover, air pollutions, VAR simulation, impulse response function

\section{Introduction}

Science park, also named as Technology park, is an industrial area planned and developed by governments with a purpose to find a cluster of companies and manufacturers that focus on research and development (R\&D) for promoting high-tech industry (Huang et al., 2016). The first science park in the world was the Stanford Research Park in the U.S.A. founded in 1951, which has created better environment for high-tech industrialization. Even if many science parks around the world claimed to have low pollution and low consumption (Huang et al., 2016), they emitted pollutants in reality that posed a great environmental risk on local or neighbored area, however less attentions were attracted from the government, non-governmental organizations $\left(\mathrm{NGO}_{\mathrm{s}}\right)$ and the public. In addition, pollution emission is an important index to evaluate whether 
a science park is truly representative of high-tech industry. (Chein et al., 2005). Therefore, it is urgent to investigate the relationship between economic development and air pollution for science parks.

Hsinchu Science Park was built in the north of Taiwan and managed by the Ministry of Science and Technology (MOST), the coordinates are 24.7829 N, $121.0058 \mathrm{E}$ (as seen in Figure 1). By the end of 2016, Hsinchu Science Park has assembled 485 hightech manufacturers which are classified into various industries such as semi-conductors, computers, communications, optoelectronics, precision machinery, biotechnology. The realized total turnover reached 1000 billion NTD which accounted for $12 \%$ of Taiwan's GDP. It is ranked as one of the fastest growing parks globally by the SIT SELECTION (U.S.A). However, Hsinchu Science Park suffered from air pollutions such as $\mathrm{PM}_{10}$, $\mathrm{SO}_{2}, \mathrm{NO}_{\mathrm{x}}$, and volatile organic compounds $\left(\mathrm{VOC}_{\mathrm{s}}\right)$ which were attributed to defective air pollution equipment during the economic and technological innovations (Alastuey et al., 2016; Cesari et al., 2016; Huang et al., 2008; Schwarz et al., 2016; Tsai et al., 2011). Conflicts between local residents and governments have also broken out in the past years such as in the Daqi Village, a neighbor of Hsinchu Science Park, which suffered from fugitive foul odor in 1999 and arsenic pollution in 2007.

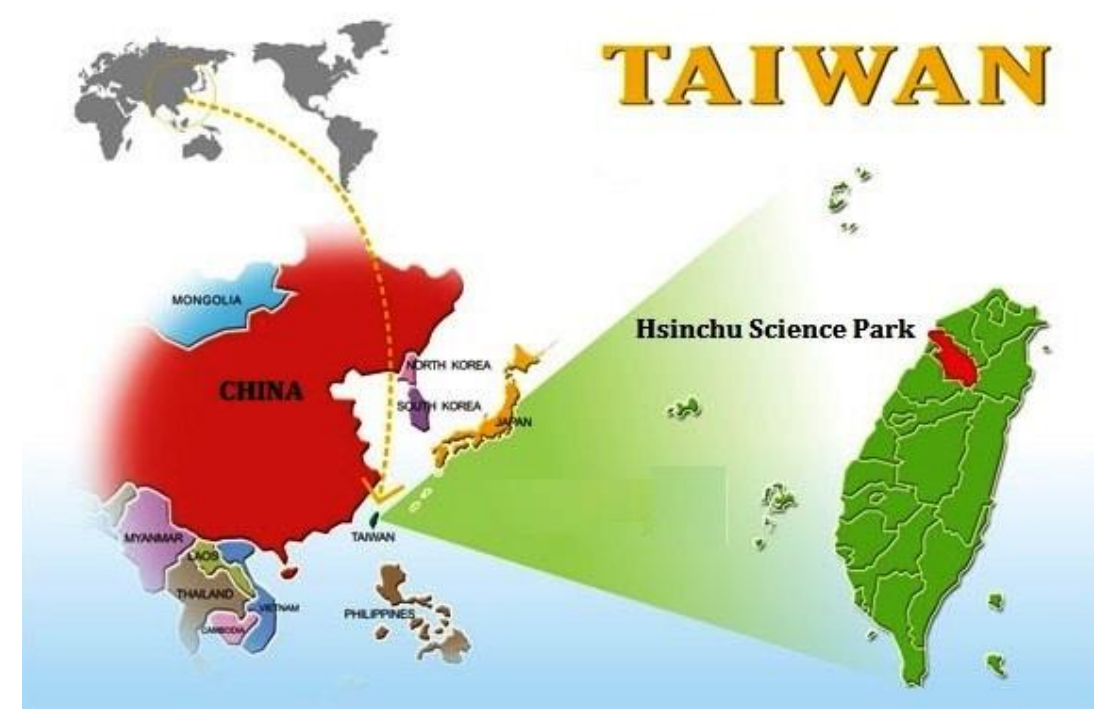

Figure 1. Location of Hsinchu Science Park in Taiwan

Previous research studies regarding the relationship between economic development and air pollution often focused on a large region, such as a country, a province, and a city. A relatively smaller area, such as a science park, is seldom explored by empirical model. In summary, this study aims to explore the relationship between economic performance and air pollution of Hsinchu Science Park by using Vector Auto Regression (VAR) model, which has been widely applied for the analysis of the relationship (Li et al., 2009; Narayan et al., 2008; Nasir and Rehman, 2011; Peng and Bao, 2006). This study not only investigated the relationship between the economic performance with the air pollution, but also adopted impulse response function to analyze it for a long period of 24 years. Also, it was evaluated whether Hsinchu Science Park was an environmentally friendly unit or not by using the VAR model. The 
conclusion could also be supplied as a scientific reference for the governments to make informed decisions.

\section{Methods}

\section{Definition of variables}

The performance, as one of the subjects, is an important indicator of competitiveness. The performance of science parks is a comprehensive system containing various subset factors such as economic performance, innovation performance, and management performance. The total business turnover is a common indicator to evaluate the economic performance (Huang et al., 2016; Wu et al., 2006) which equals to the subtraction of accumulation of deductible items (the sum of bill collection, sales of fixed assets, sales of wastes, income of interests, presentation of gifts) from the net revenue of manufacturers in a science park (the sum of sales in the declaration, total of receipt notes, sales return and discounts, and sales adjustment of previous period). Whether a science park is successful or not is mainly evaluated by its contributions to the growth of regional GDP and economics. Thus, the total business turnover of manufacturers in Hsinchu Science Park was adopted as the only output variable to represent the park performance. The effect of different industries on the economic performance could be neglected in this study because the total business turnover was collected from overall industries in Hsinchu Science Park (Chu et al., 2004; Huang et al., 2016).

Because of the complexity of air pollution species, $\mathrm{SO}_{2}, \mathrm{O}_{3}, \mathrm{NO}_{\mathrm{x}}, \mathrm{CO}, \mathrm{PM}_{10}$ which were emitted from the coal-fired power station, the exhaust of motor vehicles etc., were selected according to the Pollutant Standard Index (PSI) in Taiwan and their corresponding concentrations were used as the indices of air pollution. They were adopted as the independent variables for investigating the effect of air pollution on the park performance as shown in Table 1.

Table 1. Pollutant concentrations and vice pollution index value table for Taiwan

\begin{tabular}{|c|c|c|c|c|c|c|}
\hline \multirow{4}{*}{$\begin{array}{l}\text { PSI value } \\
\text { and their } \\
\text { impact on } \\
\text { health }\end{array}$} & Pollutants & $\mathbf{P M}_{10}$ & $\mathrm{SO}_{2}$ & $\mathrm{CO}$ & $\mathrm{O}_{3}$ & NOx $_{x}$ \\
\hline & $\begin{array}{l}\text { Statistical } \\
\text { methods }\end{array}$ & $\begin{array}{l}24 \text { Hour } \\
\text { average }\end{array}$ & $\begin{array}{l}24 \text { Hour } \\
\text { average }\end{array}$ & $\begin{array}{c}24 \text { Hour } \\
\text { maximum 8- } \\
\text { hour average }\end{array}$ & $\begin{array}{c}24 \text { Hour } \\
\text { maximum } \\
\text { value of the } \\
\text { hour }\end{array}$ & $\begin{array}{c}24 \text { Hour } \\
\text { maximum } \\
\text { value of the } \\
\text { hour }\end{array}$ \\
\hline & Unit & $\mu \mathrm{g} / \mathrm{m}^{3}$ & $\mathrm{ppb}$ & ppm & $\mathrm{ppb}$ & $\mathrm{ppb}$ \\
\hline & PSI & & & & & \\
\hline Good & 50 & 50 & 30 & 4.5 & 60 & - \\
\hline Moderate & 100 & 150 & 140 & 9 & 120 & - \\
\hline Unhealthy & 200 & 350 & 300 & 15 & 200 & 600 \\
\hline $\begin{array}{c}\text { Very } \\
\text { Unhealthy }\end{array}$ & 300 & 420 & 600 & 30 & 400 & 1200 \\
\hline \multirow{2}{*}{ Hazardous } & 400 & 500 & 800 & 40 & 500 & 1600 \\
\hline & 500 & 600 & 1000 & 50 & 600 & 2000 \\
\hline
\end{tabular}


The total business turnover was gathered from the official website of Hsinchu Science Park and the concentrations of $\mathrm{SO}_{2}, \mathrm{O}_{3}, \mathrm{NO}_{x}, \mathrm{CO}, \mathrm{PM}_{10}$ were from statistical database of EPA's air quality webpage. The annual total business turnover and annual average concentrations of $\mathrm{SO}_{2}, \mathrm{O}_{3}, \mathrm{NO}_{\mathrm{x}}, \mathrm{CO}, \mathrm{PM}_{10}$ were collected during the years from 1993 to 2016 since management system and statistical techniques were not completely established until 1992. The Long-term data would ensure the reliability of the causality inference (Alastuey et al., 2016; Pokorná et al., 2018; Rindfleisch et al., 2008).

\section{Establishment of the model}

VAR model is good at predicting interrelated time series systems and analyzing long term dynamic impact of stochastic disturbance on variables, and beneficial for understanding various economic shocks on economic variables, with advantages of preventing missing of important variables, and diminishing errors of endogenous variables (Lütkepohl, 1993). This study established impulse response function proposed by Sims (1980) using VAR model to analyze long-term impact of the economic performance on the shock of air pollutions of $\mathrm{SO}_{2}, \mathrm{O}_{3}, \mathrm{NO}_{\mathrm{x}}, \mathrm{CO}$ and $\mathrm{PM}_{10}$ in Hsinchu Science Park as seen in Equation 1:

$$
\begin{aligned}
\mathrm{P}_{t}=B_{0} & +\sum_{p=1}^{k} \theta_{11 p}\left(P_{t-p}\right) \\
& +\sum_{p=1}^{k} \theta_{12 p}\left(\boldsymbol{S O}_{2 t-p}\right) \\
& +\sum_{p=1}^{k} \theta_{13 p}\left(\boldsymbol{O}_{3 t-p}\right) \\
& +\sum_{p=1}^{k} \theta_{14 p}\left(\mathbf{N O}_{2 t-p}\right) \\
& +\sum_{p=1}^{k} \theta_{15 p}\left(\boldsymbol{C O}_{t-p}\right) \\
& +\sum_{p=1}^{k} \theta_{16 p}\left(\boldsymbol{P M}_{10 t-p}\right)+\varepsilon_{1 t}
\end{aligned}
$$

where dependent variable $\mathbf{P}$ is the economic performance of Hsinchu Science Park (100 Million TWD); $\mathbf{S O}_{2}$ is the concentration of sulfur dioxide (ppb), $\mathbf{O}_{3}$ is the concentration of ozone (ppb), NO $\mathbf{x}$ is the concentration of nitrogen dioxide (ppb), $\mathbf{C O}$ is the concentration of carbon monoxide (ppm), $\mathbf{P M}_{10}$ is the concentration of $\mathbf{P M}_{10}\left(\mu \mathrm{g} / \mathrm{m}^{3}\right)$; $B_{0}$ is the estimated coefficient, $\mathrm{t}$ is time, and $\varepsilon$ is a constant error.

The Linear regression equation was analyzed using EViews 6.0 program. Descriptive 
statistics, analysis of stability and cointegration test were performed respectively. At last, it was analyzed that impulse response functions of the impact of economic performance on air pollutions of $\mathrm{SO}_{2}, \mathrm{O}_{3}, \mathrm{NO}_{\mathbf{x}}, \mathrm{CO}, \mathrm{PM}_{10}$ and continuity impact.

\section{Results and discussions}

\section{Descriptive statistics}

Descriptive statistics analyzed the means and standard deviations of variables as shown in Table 2. The correlation coefficient matrix shows the economic performance was significantly correlated with $\mathbf{O}_{3}$, and showed a relatively significant correlation with $\mathbf{S O}_{2}, \mathbf{O}_{3}$ and $\mathbf{P M}_{10}$. The result of Hausman test is 17.98 , random probability is significant, and DW (Durbin Watson stat) is 1.67. The result of regression analysis shows that $\mathrm{R}^{2}$ is 0.79 , and the random effect of variables is significant. Meanwhile, by calculating the AR (Vector Regression) characteristic polynomial, it is found that reciprocals of characteristic polynomial are smaller than 1 , and located within the unit circle (as shown in Figure 2). The result suggests that the variables are stable for the economic system which consisted of the economic performance of Hsinchu Science Park and air pollution concentrations of $\mathrm{SO}_{2}, \mathrm{O}_{3}, \mathrm{NO}_{\mathrm{x}}, \mathrm{CO}$ and $\mathrm{PM}_{10}$. And therefore it is verified that the established model was stable.

Table 2. Means, standard deviations, and correlations of variables

\begin{tabular}{cccccccccc}
\hline & Variables & Mean & S.D. & $\mathbf{P}$ & $\mathbf{S O}_{\mathbf{2}}$ & $\mathbf{O}_{\mathbf{3}}$ & NO $_{\mathbf{x}}$ & $\mathbf{C O}$ & $\mathbf{P M}_{\mathbf{1 0}}$ \\
\hline 1 & $\mathbf{P}$ & 7543.83 & 3467.65 & 1 & & & & & \\
2 & $\mathbf{S O}_{\mathbf{2}}$ & 4.72 & 2.87 & $-.47^{*}$ & 1 & & & & \\
3 & $\mathbf{O}_{\mathbf{3}}$ & 22.56 & 6.41 & $.76^{* *}$ & -.19 & 1 & & & \\
4 & $\mathbf{N O}_{\mathbf{x}}$ & 18.64 & 2.47 & .17 & -.01 & -.15 & 1 & & \\
5 & $\mathbf{C O}$ & .53 & .056 & -.17 & -.24 & -.25 & .24 & 1 & \\
6 & $\mathbf{P M}_{\mathbf{1 0}}$ & 50.23 & 5.92 & $-.56^{*}$ & $.47^{*}$ & $-.68^{* *}$ & .28 & .01 & 1 \\
\hline
\end{tabular}

Notes: $*$ p-value $<0.05 ; * *$ p-value $<0.01$



Figure 2. Inverse roots of AR characteristic polynomial 


\section{Variable balance test}

This study tests the stability of the variables by Augmented Dickey Fuller Test (ADFT) proposed by Said and Dickey (Said and Dickey, 1984). The optimal lag period was determined by using the minimum criterion of Akaike Information Criterion (AIC) to ensure autocorrelation of residuals (Enders, 2004). The results showed that the horizontal sequence of $\mathbf{P}, \mathbf{P M}_{10}$ and $\mathbf{O}_{3}$ was not stable at a significance level of 0.05, but it became stable through first order difference. Each variable of the equation was used as an independent variable after the lag of second order as shown in Table 3.

Table 3. Results of unit root test

\begin{tabular}{c|c|c|c|c|c}
\hline Variable & $\begin{array}{c}\text { Test type } \\
(\mathrm{c}, \mathrm{T}, \mathrm{d})\end{array}$ & ADF statistics & $\begin{array}{c}\mathrm{t} \text { statistical } \\
\text { value }\end{array}$ & $\begin{array}{c}\text { Adjoint } \\
\text { probability P }\end{array}$ & Conclusion \\
\hline $\mathrm{P}$ & $(\mathrm{c}, \mathrm{T}, 1)$ & -1.710267 & -3.574244 & 0.4105 & Instable \\
\hline $\mathrm{D}(\mathrm{P})$ & $(\mathrm{c}, 0,1)$ & $-5.266976^{* * *}$ & -2.971853 & 0.0006 & Stable \\
\hline $\mathbf{S O}_{\mathbf{2}}$ & $(\mathrm{c}, 0,0)$ & $-20.65626^{* * *}$ & -3.029970 & 0.0000 & Stable \\
\hline $\mathbf{O}_{\mathbf{3}}$ & $(\mathrm{c}, 0,0)$ & -2.856286 & -3.040391 & 0.0704 & Instable \\
\hline $\mathrm{D}\left(\mathbf{O}_{3}\right)$ & $(\mathrm{c}, 0,1)$ & $-5.399642^{* * *}$ & -3.040391 & 0.0004 & Stable \\
\hline $\mathbf{N O}_{\mathbf{x}}$ & $(\mathrm{c}, 0,0)$ & $-4.377785^{* * *}$ & -3.029970 & 0.0032 & Stable \\
\hline $\mathbf{C O}$ & $(\mathrm{c}, 0,0)$ & $-3.247647^{* *}$ & -3.029970 & 0.0328 & Stable \\
\hline $\mathbf{P M}_{\mathbf{1 0}}$ & $(\mathrm{c}, 0,0)$ & -1.817124 & -3.029970 & 0.3614 & Instable \\
\hline $\mathrm{D}\left(\mathbf{P M}_{\mathbf{1 0}}\right)$ & $(\mathrm{c}, 0,1)$ & $-3.313729^{* *}$ & -3.040391 & 0.0296 & Stable \\
\hline
\end{tabular}

Note: (c, T, d) separately stand for intercept, time trend and lag order of the equation in the test; the lag order is determined by using SC minimum error criteria; D $(\mathrm{X})$ is X's first order difference; “*”, “**” and "***" mean refusal of null hypothesis at significance level of $10 \%, 5 \%$, and $1 \%$

The time series of individual variables was not stable. Thus, the cointegration test proposed by Johansen (1995) was used to identify whether there were underlying stable time series and long-term balanced relationship between these unstable variables with the linearity. The results were substituted into the cointegration Equation 1 and thus evolved in Equation 2:

$$
\begin{gathered}
\mathbf{P}_{\mathrm{t}}=+549.1754 \mathbf{S O}_{2}-612.5936 \mathbf{O}_{3}- \\
(288.46)
\end{gathered}
$$

Given cointegration Equation 2 and Figure 2, the economic performance $\mathbf{P}$ of 
Hsinchu Science Park had a long-term relationship with $\mathbf{S O}_{2}, \mathbf{O}_{3}, \mathbf{N O}_{\mathbf{x}}$ and $\mathbf{C O}$, while its relationship with PM10 was weak enough to ignore. It was a significant positive correlation of $\mathbf{P}$ with $\mathbf{S O}_{2}$ and $\mathbf{C O}$. In other words, when $\mathbf{S O}_{2}$ and $\mathbf{C O}$ increase in Hsinchu Science Park, the economic performance of $\mathbf{P}$ increases. While it was a significant negative correlation between $\mathbf{P}$ with $\mathbf{O}_{\mathbf{3}}$ and $\mathbf{N O}_{\mathbf{x}}$, suggesting when $\mathbf{O}_{\mathbf{3}}$ and NO $\mathbf{x}_{\mathbf{x}}$ increase, $\mathbf{P}$ decreases.

\section{$V A R$ 's impulse response function analysis}

The VAR's impulse response function is the sum of a standard deviation, stochastic disturbance term to impact another current, and future values of various variables. It simulates the dynamic interaction among the variables (Enders, 2004). The object of this study is to investigate the response to the independent variable $\mathbf{P}$ within the system to the air pollution concentrations in different periods, and the contribution of air pollution concentrations to $\mathbf{P}$. As seen in Figure 3, the horizontal axis is the hysteresis effect period of the shock with a maximum of 10 periods. The vertical axis is the impulse response function of a dependent variable to an independent variable. The blue solid line is the dynamic path of the impulse response function, and the two red dotted lines are confidence intervals which are twice the standard deviation.

As shown in Figure 3(a), economic performance has a positive response to performance. It drops to the lowest point in the fourth period, and then gradually converges to zero line, meaning that the effect of investment on the future economic performance was promoting its growth in the first two periods and then the effect gradually decreased to zero. This trend reflects that the economic performance of Hsinchu Science Park targets at the processing and exports and few enterprises make continuous investments to improve the business environment in the science park. Figure $3(b)$ shows the impulse response of the economic performance to $\mathbf{S O}_{2}$. After a positive shock is given to $\mathbf{S O}_{2}$ in the current period, the response function drops to the lowest point in the second period, and then converges gradually. This means there is no significant impact on $\mathbf{S O}_{2}$ by the growth of economic performance of Hsinchu Science Park in the whole current. Figure 3(c) shows the impulse response function of economic performance of Hsinchu Science Park to NOx. After a positive shock is given to $\mathbf{N O}_{\mathbf{x}}$ in this current period, the response reaches the lowest point of the negative response in the third period, and converges gradually from the beginning of the fourth period. This also indicates that there is no significant impact on $\mathbf{N O}_{\mathbf{x}}$ by the growth of the economic performance in the current period. Figure $3(d)$ shows an impulse response function of economic performance to PM10. The response nearly approaches zero line in the first and second period, and drops to the negative response at the beginning of the third period. It converges gradually on the fifth period reaching a negative point. This indicates that the economic performance of the science park has no significant impact on $\mathrm{PM}_{10}$ in the current period. In view of air pollutant sources, $\mathrm{SO}_{2}$ is mainly emitted from thermal power plants, steel plants and petrochemical plants, while $\mathrm{NO}_{\mathrm{x}}$ and $\mathrm{PM}_{10}$ are from the exhaust of vehicles, thermal plants, nitric acid making plants and municipal waste incineration plants in Taiwan (Tsai et al., 2011). On the other hand, the majority of these pollutants were more possibly from the neighboring areas or even further areas such as the mainland of China and Northeast Asia through oversees transportation (Chou et al., 2008; Chou et al., 2010; Shaw et al., 2004). The results are in agreement with the fact that Hsinchu Science Parks excludes these heavy industries to build and operate. Stringent control procedures have been formulated and conducted, and the air 
pollution have also been effectively supervised by environmental management of the science park. Thus, it concludes that Hsinchu Science Park is environmentally friendly. The impulse response function of economic performance to $\mathbf{O}_{3}$ is shown in Figure 3(e). After a positive shock is given to $\mathbf{O}_{3}$ in the current period, a negative response at the beginning climbs to the highest point of positive response in the third period, and drops to the lowest point in the fifth period, and then converges to zero gradually.
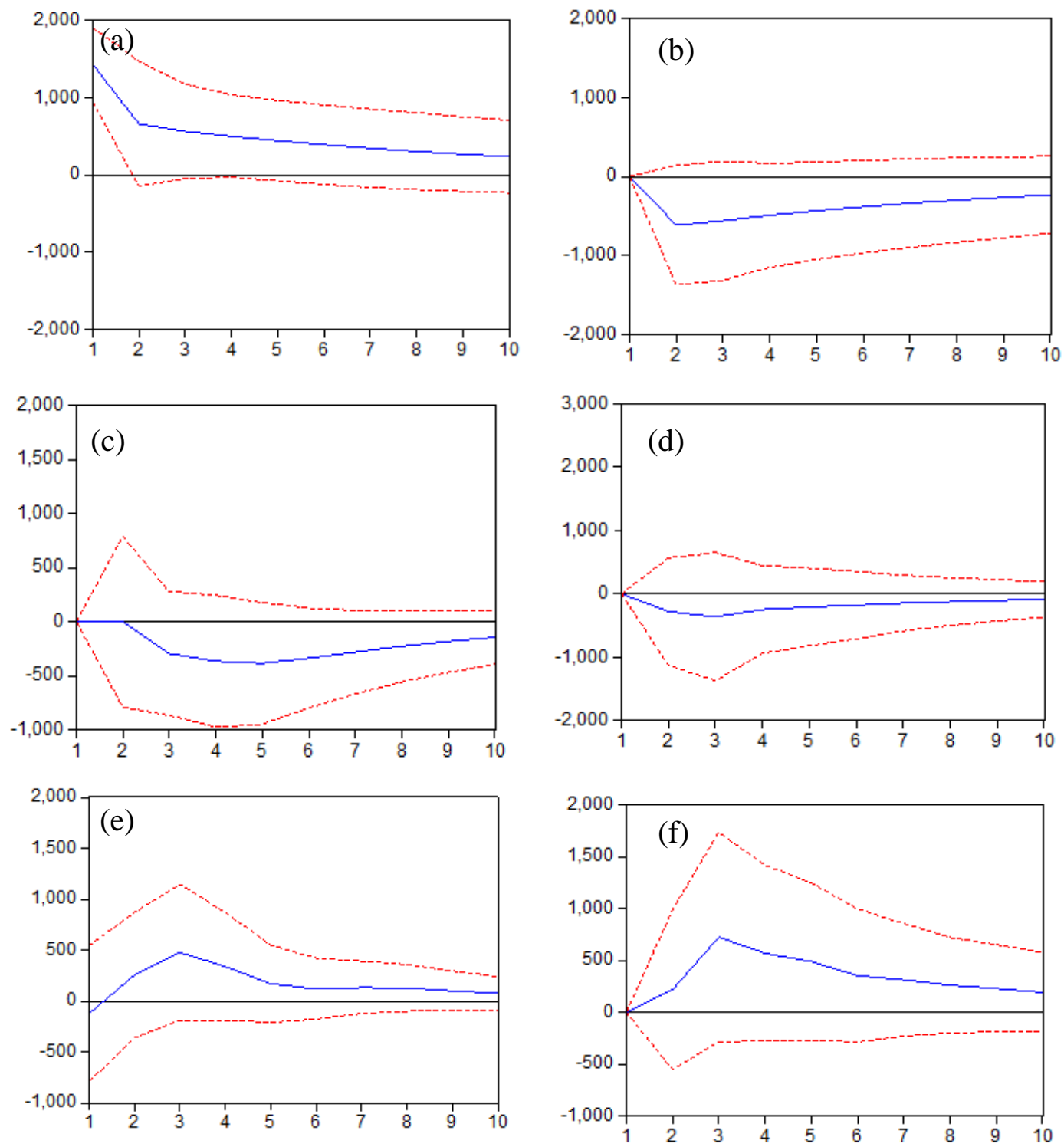

Figure 3. The impulse response function of dependent variables to independent one(a) Response of $\boldsymbol{P}$ to $\boldsymbol{P},(\boldsymbol{b})$ Reponses of $\boldsymbol{P}$ to $\mathrm{SO}_{2},(\boldsymbol{c})$ Response of $\boldsymbol{P}$ to $\mathrm{NO}_{x},(d)$ Response of $\boldsymbol{P}$ to $\boldsymbol{P M}_{10},(\boldsymbol{e})$ Reponses of $\boldsymbol{P}$ to $\boldsymbol{O}_{3}$, and $(\boldsymbol{f})$ Response of $\boldsymbol{P}$ to $\boldsymbol{C O}$

This indicates that there is a significant impact of the economic performance growth on $\mathrm{O}_{3}$ in the current period. The impulse response function of economic performance to $\mathbf{C O}$ is shown in Figure 3(f). The impulse response rises to the highest point of positive response in the third period, and drops to the lowest point, and then converges gradually 
to zero line. This indicates that there is a significant impact of the growth of economic performance on $\mathbf{C O}$ in the current period. When the economic performance improved, more products would be produced and then the input of energy and raw materials increased. More $\mathrm{O}_{3}$ and $\mathrm{CO}$ were emitted during the enlarged production process. There are two main sources of $\mathrm{O}_{3}$ pollution in Hsinchu Science Park. Firstly, $\mathrm{O}_{3}$ as a secondary pollutant results from the photo-oxidation between $\mathrm{O}_{2}$ and the emitted NMHCs (non-methane hydrocarbons) which are emitted in large amounts in various processes of the high-tech industry, such as wafer process, welding, etching, image process, and chemical washing in IC, photo electricity and biotech industries (Price et al, 2004). The other source is the diffusion of $\mathrm{O}_{3}$ as the primary pollutant in the advanced oxidation water-treatment system where high concentration of $\mathrm{O}_{3}$ is present (Went et al., 2009). CO comes from the exhaust of vehicles because road logistics is a main transportation in Hsinchu Science Park with a tremendous amount of logistics caused by economic development.

\section{Suggestions}

Many countries are activated to develop green economy and green industry in the world. The World Trade Organization (WTO) has exceptional clauses on environmental protection, which imposes green tax on exported goods because the pressure of environmental protection from the international society becomes more and more intense. In this context, low-carbon science parks have been promoted to facilitate the development of low carbon economy, which is beneficial for sustainable development (Gearty, 2008).

The governments should formulate tax systems to promote green economy. A green tax system can be established by using tax leverage to solve prisoner's dilemma between environment and economic development. Moreover, they should formulate incentives and subsidy systems for clean production which shift pollution control towards overall pollution prevention, as well as actively guide enterprise to implement carbon tradition and establish carbon investigation system.

Science parks should be planned and managed based on the concept of sustainable development. The science park management should also shift from end-of-pipe treatment to pollution prevention, conduct evaluation of environmental impact, obtain pollutants discharge license, and implement centralized disposal of waste in accordance with the national and local regulations or standards to prevent air pollution.

The enterprises in science parks should promote green sustainable economic development through $\mathrm{R} \& \mathrm{D}$, management system, and green technologies. They need to develop green and energy-efficient products. Enterprises should also establish ISO14000, clean production, energy management, green supply chain and environment management system. These measures can reduce expenses in pollution prevention, save raw material or products, improve efficiency and quality of production, and prevent occupational disease.

\section{Research limitations}

Because of limitations of data sources, this study has some limitations. Firstly, different industries caused the variation of air pollutions concentrated. Secondly, the air pollution species caused by high-tech enterprises were not considered in this study. These should be considered in future research. 


\section{Conclusion}

This study investigated the relationship between the economic performance and air pollution of $\mathbf{S O}_{2}, \mathbf{O}_{3}, \mathbf{N O}_{\mathbf{x}}, \mathbf{C O}, \mathbf{P M}_{10}$ in Hsinchu Science Park from 1993 to 2012. VAR's impulse response function was used to analyze the effect of the science park performance on $\mathbf{S O}_{2}, \mathbf{O}_{3}, \mathbf{N O}_{\mathbf{x}}, \mathbf{C O}$ and $\mathbf{P M 1 0}$. The results showed that the park performance has a tight, long-term and stable relationship with air pollution. The park performance is negatively correlated to $\mathbf{S O}_{2}, \mathbf{N O}_{\mathbf{x}}$ and $\mathbf{P M} \mathbf{1 0}_{\mathbf{1 0}}$. The hysteresis effect of the park performance could be neglected on $\mathbf{S O}_{2}, \mathbf{N O}_{\mathbf{x}}$ and $\mathbf{P M} 10$ as they are not emitted from Hsinchu Science Park but from oversees transportation possibly. On the other hand, the performance is correlated positively to $\mathbf{O}_{3}$ and $\mathbf{C O}$. The hysteresis effect of the park performance on $\mathbf{O}_{3}$ and $\mathbf{C O}$ is significant, due to the large emission from the production process and transportation in Hsinchu Science Park. Since science parks cause air pollution, the government should encourage enterprises to develop better R\&D capabilities to reduce pollution and energy consumption. Meanwhile, the enterprises should develop environmental protection mechanisms actively.

Acknowledgements. This study was supported by "Guangdong Social Science Planning Project" (GD17XGL15).

\section{REFERENCES}

[1] Alastuey, A., Querol, X., Aas, W., Lucarelli, F., Perez, N., Moreno, T., Cavalli, F., Areskoug, H., Balan, V., Catrambone, M., Ceburnis, D., Cerro, J. C., Conil, S., Gevorgyan, L., Hueglin, C., Imre, K., Jaffrezo, J. L., Leeson, S. R., Mihalopoulos, N., Mitosinkova, M., O'Dowd, C. D., Pey, J., Putaud, J. P., Riffault, V., Ripoll, A., Sciare, J., Sellegri, K., Spindler, G., Yttri, K. E. (2016): Geochemistry of PM10 Pver Europe during EMEP Intensive Measurement Periods in Summer 2012 and Winter 2013. - Atmos. Chem. Phys. 16:6107-6129. https://doi.org/10.5194/acp-16-6107-2016

[2] Cesari, D., Donateo, A., Conte, M., Merico, E., Giangreco, A., Giangreco, F., Contini, D. (2016): An inter-comparison of PM2.5 at urban and urban background sites: chemical characterization and source apportionment. - Atmospheric Research 174-175: 106-119.

[3] Chein, H. M., Hsu, Y. D., Aggarwal, S. G., Chen, T. M., Huang, C. C. (2005): Evaluation of arsenical emission from semiconductor and opto-electronics facilities in Hsinchu Taiwan. Atmospheric Environmental 40(10): 1901-1907.

[4] Chien, C. F., Chen, C. P., Lin, K. Y. (2013): An investigation of planning a research park in Hsinchu science park area. - Journal of Management \& Systems 20(2): 227-255.

[5] Chou, C. C.-K, Lee, C. T., Cheng, M. T., Yuan, C. S., Chen, S. J., Wu, Y. L., Hsu, W. C., Lung, S. C., Hsu, S. C., Lin, C. Y., Liu, S. C. (2010): Seasonal Variations and Spatial Distribution of Carbonaceous Aerosols in Taiwan. - Atmos. Chem. Phys. Discuss 10: 9563-9578.

[6] Chou, Charles C. K., Lee, C. T., Yuan, C. S., Hsu, W. C., Lin, C. Y., Hsu, S. C., Liu, S. C. (2008): Implications of the Chemical Transformation of Asian Outflow Aerosols for the Long-range Transport of Inorganic Nitrogen Species. - Atmos. Environ 42(32): 7508-7519.

[7] Chu, P. Y., Tzeng, G. H., Teng, M. J., Chiu, H. (2004): A multivariate analysis of the relationship among market share, growth and profitability--The case of the science-based industrial park. - Sun Yat-Sen Management Review 12(3): 507-533.

[8] Enders, W. (2004): Applied econometric time series (2 ed.). - Willey: New Jersey.

[9] Gearty, M. (2008): Achieving carbon reduction. - Journal of Corporate Citizenship 30:81-94.

[10] Huang, S. Z., Wu, T. J., Tsai, H. T. (2016): Hysteresis effects of R\&D expenditures and patents on firm performance: An empirical study of Hsinchu Science Park in Taiwan. - 
Filomat 30(15): 4265-4278.

[11] Huang, W. M., Lee, W. M., Wu, C. C. (2008): GHG emissions, GDP growth and the Kyoto Protocol: A revisit of Environmental Kuznets Curve hypothesis. - Energy Policy 36(1): 239-247.

[12] Johansen, S. (1995): Likelihood-Based Inference in Cointegrated Vector Autoregressive Model. - Oxford: Oxford University Press.

[13] Li, L., Zhu, J. S., Gao, R. X. (2009): The study on relationship between economic growth and environmental pollution in chongqing base on VAR model. - Journal of Southwest University 31(11): 92-96.

[14] Lütkepohl, H. (1993): Introduction to Multiple Time Series Analysis. - Springer-Verlag.

[15] Narayan, P. K., Narayan, S., Prasad, A. (2008): A structural VAR analysis of electricity consumption and real GDP: Evidence from the G7 countries. - Energy Policy 36(7): 27652769.

[16] Nasir, M., Rehman, F. U. (2011): Environmental Kuznets Curve for carbon emissions in Pakistan: An empirical investigation. - Energy Policy 39 (3): 1857-1864.

[17] Peng, S. J., Bao, Q. (2006): Economic growth and environmental pollution: an empirical analysis based on China's time series data (1985 2003). - Contemporary Finance \& Economics 2006 (7): 5-12.

[18] Pokorná, P., Schwarz, J., Krejci, R., Swietlicki, E., Havránek, V. (2018): Comparison of PM2.5 chemical composition and sources at a rural background site in Central Europe between 1993/1994/1995 and 2009/2010: Effect of legislative regulations and economic transformation on the air quality. - Environmental Pollution 241: 841-851.

[19] Price, H. U., Jaffe, D. A., Cooper, O. R., Doskey, P. Y. (2004): Photochemistry, ozone production, and dilution during long-range transport episodes from Eurasia to the northwest United States. - Journal of Geophysical Research-Atmospheres 109 (23): doi:10.1029/2003JD004400.

[20] Rindfleisch, A., Malter, A. J., Ganesan, S., Moorman, C. (2008): Cross-sectional versus longitudinal survey research: Concepts, findings, and guidelines. - Journal of Marketing Research 45(3): 261-279.

[21] Said, S. E., Dickey, D. A. (1984): Testing for unit roots in autoregressive-moving average models of unknown order. - Biometrika 71: 599-607.

[22] Schwarz, J., Cusack, M., Karban, J., Chalupníckova, E., Havranek, V., Smolík, J., Zdímal, V. (2016): PM2.5 chemical composition at a rural background site in central Europe, including correlation and air mass back trajectory analysis. - Atmospheric Research 176-177: 108-120.

[23] Shaw, C. L., Lee, C. T., Cheng, M. T., Yuan, C. S., Wu, Y. L., Chen, S. J., Lin, P. H., Lin, C. Y., Lung, S. C., Chou, C. C., Liu, T. H., Hsu, S. C., Chang, C. C. (2004): Impacts of Long-Range Transport on Air Pollutants in Taiwan. - Journal of Arid Land Resources and Environment 18(1): 203-210.

[24] Sims, C. A. (1980): Macroeconomics and reality. - Econometrica 48: 1-48.

[25] Tsai, H. H., Yuan, C. S., Hung, C. H., Lin, Y. C. (2011): Physicochemical Properties of PM2.5 and PM2.5-10 at Inland and Offshore Sites over Southeastern Coastal Region of Taiwan Strait - Aerosol and Air Quality Research 11: 663-677.

[26] Tsai, H. H., Yuan, C. S, Hung, C. H., Lin, C., Lin, Y. C. (2011): Influence of Sea-Land Breezes on the Tempospatial Distribution of Atmospheric Aerosols over Coastal Region. Journal of Air and Waste Management Association 61: 358-376.

[27] Went, E. C., Rosario-Ortiz, F. L., Snyder, S. A. (2009): Effect of ozone exposure on the oxidation of trace organic contaminants in waste water. - Water Research 43 (4): 1005-1014.

[28] Wu, W. Y., Tsai, H. J., Chang, K. Y., Lai, M. K. (2006): Assessment of intellectual capital management in Taiwanese IC design companies: Using DEA and the malmquist productivity index. - R\&D Management 36(5): 531-547. 